\title{
Comparative Analysis of Communication System of Farmers and Farm Women with the Extension Methods and Materials
}

\author{
Bibhu Santosh Behera ${ }^{1 *}$ and Bibhuti Prasad Mohapatra ${ }^{2}$ \\ ${ }^{1}$ Department of Extension Education, College of Agriculture, OUAT, \\ Bhubaneswar-751003, Odisha, India \\ ${ }^{2}$ Department of Extension Education, C.A., OUAT, Bhubaneswar (Guide), India \\ *Corresponding author
}

A B S T R A C T

Keywords

Gender,

Communication,

Analysis, Materials,

Methods

Article Info

Accepted:

20 November 2019

Available Online:

10 December 2019
The Communication System being used by Farmers and Farm women may be same or variable as per the frequency of use of various Extension Methods and also various materials. Here the authors were cited the comparative analysis of various extension methods like individual, group and mass and various audiovisual, non-audio visual and locally existing methods. In the Year 2013-2018, a pilot based research was made by the PhD Research Scholar under the guidance of Doctoral Research Committee with the help of OUAT, KVK and Agriculture Department to publish this research review before the researchers for further study. The study was completed in Keonjhar, Dist. of Odisha. Here Expost facto design and multistage sampling was taken for study along with Structured interview schedule by personal interview, telephonic call, email method followed for collection of data. Around 120 farm women and 120 male farmers' samples were taken for comprehensive study in Keonjhar, Dist. of Odisha. This Research Paper has been published for partial fulfillment of award of PhD Degree by OUAT, Bhubaneswar in NAAS-5 Rated journal. This is in accordance with UGC Rule for completion of PhD with best quality.

\section{Introduction}

Gender Play a Vital role in the Society. In the era of Research, now-a-days every country and also whole world follow the thumb rule of Gender Studies. As Gender may be classified 3 types such as 1. Male 2. Female and 3. Transgender, so we can make gender comparative studies in every aspects like Gender in various field of studies. Here I have taken the above research problem entitled as "A Gender Comparative Study on Communication System among the farmers and farm women in Keonjhar Dist. of Odisha" as I have a special interest to take a lucrative research based on Gender which is the current 
demand in every sector. The current communication system is mandatory for Gender and farmers to empower them and uplift in a developmental action hence be justified. According to UNEP, Gender studies should be introduced in Education Systems along with climate and environmental programs. To maintain Gender stability through gender equity and gender main streaming Gender study is important. In the era of pluralistic extension our extension communication system must be developed for Gender as Gender is the main client of any type of study and research. Here my research work will be conducted in Keonjhar Dist. Of Odisha, which is a big platform to conduct quantitative and qualitative research by taking various clients like Gender, Farmer and Tribal's along with the communication and extension system existing in this Dist. to bridge the gap among all clients.

The main objectives of this study includes analysis of communication of the farmers and farm women with the extension methods and materials.

\section{Theoretical framework}

\section{Information system}

An information system is a collection of message that transforms data into knowledge and methods desired by and useful for individual and group users in organizations and other entities.

\section{Communication}

Leagens says, "it is a process by which two or more people exchange ideas, facts, feelings or impressions in ways that each gains a common understanding of the message. In essence it is the act of getting a sender and a receiver tuned together for a particular message or series of message.

\section{Importance of communication}

Paul Leganes has very rightly said that, for development of any nation, three things are necessary, (i) investigation, (ii) interpretation and (iii) administration. Our country India is self-sufficient in investigations i.e. improved technology. Also administration is not posing any problem. But only due to lack of proper interpretation we failed to achieve significant success as compared to developed countries. Interpretation is nothing but communication.

\section{Models of communication}

Farmer: A hard working individual whom may be male or female. Provides food for everyone. They work 24 hours a day normally from a very young age. A dangerous and selfless occupation to which all should be thankful.

Farm women: In rural India, the percentage of women who depend on agriculture for their livelihood is as high as $84 \%$. Women make up about $33 \%$ of cultivators and about $47 \%$ percent of agricultural labourers

\section{Communication system}

A system or facility for transferring data between persons and equipment. The system usually consists of a collection of individual communication networks transmission systems, relay stations, tributary stations and terminal equipment capable of interconnection and interoperation so as to form an integrated whole. These individual components must serve a common purpose, be technically compatible, employ common procedures, respond to some form of control and generally operate in unison.

["Communications Standard Dictionary", 2nd Edition, Martin H. Weik].

(1995-02-06). 


\section{Comparative study}

The comparative method is often used in the early stages of the development of a branch of science. It can help the researcher to ascend from the initial level of exploratory case studies to a more advanced level of general theoretical models, invariances, such as causality or evolution.

\section{Communication constraints}

Communication constraints are nothing but the barriers and draw back in Communication Channel. Ex:-Semantic Barrier, Mirage Distoration, Fog Distoration, Technical Jargons, In adequate Message.

\section{Reviews of literature}

Umunna Nnaemeka Opara (2010), in his study, states that 21.3 percent of the farmers indicate film shows, followed by radio with $28.4 \%$ and Television with $19.1 \%$ as sources of information.

Devi and Sabharwal (2014) observed that radio and television were frequently used mass media sources by the farm women, whereas, cassette recorders, news paper, audio visual aid, farm magazine/journals, telephone calls and Internet were least frequent/ not used sources of information by farm women for seeking information regarding gram cultivation practices.

Hasan and Sharma (2011) reported that 90 percent of urban women read newspapers for taking information, news and for the entertainment. Almost 65 percent of the respondents read magazine sometimes and 10 percent read it regularly.

Jena et al., (2016) in their study "credibility of communication sources as perceived by the farm women" reported that respondents perceived VAW, relatives, posters, radio, TV, folk dance and folk songs as major/most credible source of information. Formal informal inter personal sources had exhibited significant input on the credibility of the other sources of information.

\section{Materials and Methods}

Here the Research Design is Exploratory. After Data Collection by a Valid Developed Instrument i.e. Structured Interview Schedule, data analysis has been made by using latest soft wires and basic statistics formula. The data collection has been made by Individual Farmer's Meeting, Focused Group Discussion and other social approaches.

\section{Hypothesis setting}

Ho-The Communication System Varies in the Gender Line

Ha:-The Communication System may not vary in the Gender Line.

\section{Results and Discussion}

Various extension methods and materials are available with the extension agents for transfer of technology to the farm audience. However, these extension methods and materials are situation specific and client specific. The application of the extension methods do differ on gender lines and gender wise preferences. The researcher tried the critically analyze the contacts of farmers and farm women with various extension methods as well as materials in the message communication process.

The data revealed that 20-30 percent score gap was observed in case of contact of individual methods with farmers and they were in good touch with farm and home visit and client's call where as a score gap of 2550 percent was visible in case of contact of farm women with various individual methods (Table 1 and 2). 
In comparing both the genders it was observed that the farmers are more exposed to client's call and minikit trial than the farm women with significant C.R. Value.

This implied that the farm women had less opportunity of minikit trials and significant difference was observed in contact with farmers and farm women through client's call.

However the no respondents had any contact with farm clinic which was a matter of great concern.

It was an encouraging trend that the respondents both farmer and farm women were in a good touch with exposure visit, group meeting and demonstration. However the significant $C$. R. Value with respect to result demonstration and exposure visit implied that the farm women were lagging behind the farmers in both these group communication methods. Therefore it was suggested that more number of farm women should be enrolled for result demonstration and exposure visits. This will make them more prone to adoption of technology and technical empowerment.

The result on degree of contact with mass communication method revealed that the farmer respondents were deficiently contacted through campaign and farm publications due to more illiteracy and lack of awareness for campaign.

Similarly the farm women respondents were highly deficient with respect to contact with farm publication, campaign, radio and TV message (Table 3 ).

The result also depicted that high significant difference in contact with mass communication methods through gender line. The farmers and farm women significantly differ in contact with Radio and TV message, exhibition and campaign.
Therefore it was suggested to involve more no of farm women in campaign, exhibition, radio and TV message. As the score gap is very high with respect to farm publications the village youth club should play a vital role for dissemination of technology through farm publications. The findings is in accordance with the findings with Umunna Nnaemeka Opara (2010), in his study, states that 21.3 percent of the farmers indicate film shows, followed by radio with $28.4 \%$ and Television with $19.1 \%$ as sources of information.

The researcher had tried to map the extent of contact of farmers and farm women to various visual communication materials. The result obtained clearly indicated that the farmers and farm women did not differ significantly with respect to contact with visual communication materials. Hence it may be concluded that the farmer as well as farm women respondents had less contact and exposure to various visual communication materials except banner and photographs.

Here it is suggested that the extension agent should use more number of visual materials (Poster, model and flash cards) in demonstrations and campaign to motivate the rural audience.

A communication gap of 53.33 percent was observed with the farmers' respondents with respect to Bulletin Board followed by 51.66 percent with Flash card, 43.33 percent with model and 40 percent with Chalk/White Board, revealed that the farmers were having less degree of contact with extension materials.

Similarly, in case of farm women a score gap of 60 percent was observed with respect to degree of contact with Bulletin Board followed by 56.66 percent gap incase of Flash card.Again the farm women were having high gap percentage of 53.33 percent with Poster 
and 51.66 percent with Flip chart followed by 50 percent in Model and Chalk/White Board jointly.

The data concluded that farmers were getting information from various visual materials such as Banner, Picture and photograph, Flip chart and Chalk/White Board whereas farm women were getting information from Banner, Picture and photograph, Model and Chalk/White Board.

It also revealed that there was no significant difference of degree of contact among farmers and farm women with respect to all visual materials presented in the table 4 .

The findings is in accordance with the findings with Devi and Sabharwal (2014) observed that radio and television were frequently used mass media sources by the farm women, whereas, cassette recorders, news paper, audio visual aid, farm magazine/ journals, telephone calls and Internet were least frequent/ not used sources of information by farm women for seeking information regarding gram cultivation practices.

The data with respect to contact of respondents to various written communication materials revealed that a high score gap of 43.33 percent to 60 percent was observed with respect to farmers and the figure was 58.33 percent to 63.33 percent for farm women respondents. This implied that a majority of respondents did not have contact and exposure to written and communication materials like folders, journals, leaflets etc. (Table 5).

However, the use of folder had a significant C.R. value which implied that the difference of use of folders by farmers and farm women was significant. That implied that farmers were using more folders than farm women for communication of information. As the score gap is high with respect to exposure and contact with respondents with written communication materials due to illiteracy and ignorance. The social groups, youth clubs, community centers should be sensitized by the local extension agents for increasing the contact of respondents to written and printed materials.

Wang and Dissanayake (1984), defined FOLK MEDIA as a communication system embeded in the culture which existed before the arrival of mass media, and still exists as a vital mode of communication in many parts of the world, presenting a certain degree of continuity, despite changes. The folk media consists of forms-folk theatre, puppetry, story telling, folk painting (tribal house based painting/tatoos), folk music, ballad and mime.

The table 6 reflected that out of 5 numbers of traditional media farmer respondents were getting information and knowledge from mainly folk dance and village drama $(\mathrm{MS}=2.9)$, and Puppet Show (MS=2.75).

The Scenario with respect to farm women depicted that the farm women respondents were mostly in contact with folk Dance (MS=2.8), information giving by using drum by Dakua $(\mathrm{MS}=2.7)$ and from village drama.

A communication gap of 40 percent was observed with the farmers respondents with respect to wall paintings followed by 8.33 percent in puppet show, revealed that the farmers were having high degree of contact with Traditional Media.

Similarly, in case of farm women a score gap of 56.66 percent was observed with respect to degree of contact with wall paintings followed by 13.33 percent gap incase of puppet show and 11.66 percent with village drama revealed that the farmwomen were having high degree of contact with Traditional Media. 
The data concluded that farmers and farm women of the sample area were getting information from various traditional media such as folk dance, village drama, information giving by using drum by Dakua, and puppet show.

It also revealed that there was significant difference of degree of contact among farmers and farm women with respect to traditional media with wall paintings, and village drama.Therefore it may be concluded that the farmers were getting more information than farm women through village drama and wall paintings. The findings is in accordance with the findings of Jena et al., (2016) in their study "credibility of communication sources as perceived by the farm women" reported that respondents perceived VAW, relatives, posters, radio, TV, folk dance and folk songs as major/most credible source of information. Formal informal inter personal sources had exhibited significant input on the credibility of the other sources of information (Fig. 1-3).

Table.1 Degree of contact with individual methods

\begin{tabular}{|l|c|c|c|c|c|}
\hline Group Methods & $\begin{array}{c}\text { Mean Score } \\
\text { (Farmer) }\end{array}$ & Score Gap \% & $\begin{array}{c}\text { Mean Score } \\
\text { (Farmwomen) }\end{array}$ & $\begin{array}{c}\text { Score } \\
\text { Gap \% }\end{array}$ & C.R. \\
\hline Group meeting & 2.2 & 26.66 & 2.5 & 16.66 & $1.88(\mathrm{NS})$ \\
\hline $\begin{array}{l}\text { Method } \\
\text { Demonstration }\end{array}$ & 2.7 & 10 & 2.45 & 18.33 & $1.85(\mathrm{NS})$ \\
\hline $\begin{array}{l}\text { Result } \\
\text { demonstration }\end{array}$ & 2.7 & 10 & 2.3 & 23.33 & $2.771(*)$ \\
\hline $\begin{array}{l}\text { Small group } \\
\text { training }\end{array}$ & 1.8 & 40 & 1.9 & 36.66 & $0.532(\mathrm{NS})$ \\
\hline $\begin{array}{l}\text { Field day/Farmer's } \\
\text { day }\end{array}$ & 2.1 & 30 & 1.8 & 40 & $1.62(\mathrm{NS})$ \\
\hline $\begin{array}{l}\text { Study } \\
\text { tour/Exposure visits }\end{array}$ & 2.9 & 3.33 & 2.45 & 18.33 & $3.73(* *)$ \\
\hline
\end{tabular}

Table.2 Contact with group methods

\begin{tabular}{|l|c|c|c|c|c|}
\hline Extension Methods & $\begin{array}{c}\text { Mean Score } \\
\text { (Farmer) }\end{array}$ & $\begin{array}{c}\text { Score } \\
\text { Gap \% }\end{array}$ & $\begin{array}{c}\text { Mean Score (Farm } \\
\text { women) }\end{array}$ & $\begin{array}{c}\text { Score } \\
\text { Gap \% }\end{array}$ & C.R. \\
\hline Individual Methods & 2.4 & 20 & 2.25 & 25 & $0.92(\mathrm{NS})$ \\
\hline $\begin{array}{l}\text { Farm and Home } \\
\text { visit }\end{array}$ & 2.3 & 23.33 & 1.9 & 36.66 & $2.25\left(^{*}\right)$ \\
\hline Client's call & 2.1 & 30 & 1.5 & 50 & $3.16\left(^{*}\right)$ \\
\hline $\begin{array}{l}\text { Adaptive or minikit } \\
\text { trial }\end{array}$ & N.A. & N.A. & N.A. & N.A. & N.A. \\
\hline $\begin{array}{l}\text { Agri Clinic/Farm } \\
\text { clinic }\end{array}$ & & & & & \\
\hline
\end{tabular}


Table.3 Contact with mass methods

\begin{tabular}{|l|c|c|c|c|c|}
\hline $\begin{array}{l}\text { Mass Contact } \\
\text { method }\end{array}$ & $\begin{array}{c}\text { Mean Score } \\
\text { (Farmer) }\end{array}$ & $\begin{array}{c}\text { Score } \\
\text { Gap \% }\end{array}$ & $\begin{array}{c}\text { Mean Score } \\
\text { (Farm women) }\end{array}$ & $\begin{array}{c}\text { Score } \\
\text { Gap \% }\end{array}$ & $\begin{array}{c}\text { C.R. } \\
\text { value }\end{array}$ \\
\hline TV & 2.8 & 6.66 & 2.1 & 30 & $4.672(* *)$ \\
\hline Radio & 2.5 & 16.66 & 1.7 & 43.33 & $4.50\left(^{* *}\right)$ \\
\hline Exhibition & 2.3 & 23.33 & 2.6 & 13.33 & $2.01\left(^{*}\right)$ \\
\hline Mass meeting & 2.6 & 13.33 & 2.45 & 18.33 & $1.061(\mathrm{NS})$ \\
\hline Campaign & 1.8 & 40 & 1.3 & 56.66 & $2.58(*)$ \\
\hline $\begin{array}{l}\text { Farm } \\
\text { publication }\end{array}$ & 1.3 & 56.66 & 1.2 & 60 & $0.529(\mathrm{NS})$ \\
\hline
\end{tabular}

Table.4 Contact with visual materials

\begin{tabular}{|l|c|c|c|c|c|}
\hline $\begin{array}{l}\text { Extension } \\
\text { Materials }\end{array}$ & $\begin{array}{c}\text { Mean Score } \\
\text { (Farmer) }\end{array}$ & $\begin{array}{c}\text { Score } \\
\text { Gap \% }\end{array}$ & $\begin{array}{c}\text { Mean Score } \\
\text { (Farm women) }\end{array}$ & $\begin{array}{c}\text { Score } \\
\text { Gap \% }\end{array}$ & C.R. \\
\hline Visual Materials & 1.6 & 46.66 & 1.4 & 53.33 & $1.03(\mathrm{NS})$ \\
\hline Poster & 1.7 & 43.33 & 1.5 & 50 & $1.03(\mathrm{NS})$ \\
\hline Model & 2.65 & 11.66 & 2.5 & 16.66 & $1.11(\mathrm{NS})$ \\
\hline Banner & 1.8 & 40 & 1.45 & 51.66 & $1.81(\mathrm{NS})$ \\
\hline Flip chart & 2.3 & 23.33 & 2.1 & 30 & $1.16(\mathrm{NS})$ \\
\hline $\begin{array}{l}\text { Picture and } \\
\text { photograph }\end{array}$ & 1.45 & 51.66 & 1.3 & 56.66 & $0.77(\mathrm{NS})$ \\
\hline Flash card & 1.4 & 53.33 & 1.2 & 60 & $0.98(\mathrm{NS})$ \\
\hline Bulletin Board & 1.8 & 40 & 1.5 & 50 & $1.55(\mathrm{NS})$ \\
\hline $\begin{array}{l}\text { Chalk/White } \\
\text { Board }\end{array}$ & & & & & \\
\hline
\end{tabular}

Table.5 Degree of Contact of Farmers and Farmwomen with Extension Materials for learning and communications (Written materials)

\begin{tabular}{|l|l|l|l|l|l|}
\hline $\begin{array}{l}\text { Extension } \\
\text { Materials }\end{array}$ & $\begin{array}{l}\text { Mean Score } \\
\text { (Farmer) }\end{array}$ & $\begin{array}{l}\text { Score } \\
\text { Gap \% }\end{array}$ & $\begin{array}{l}\text { Mean Score (Farm } \\
\text { women) }\end{array}$ & $\begin{array}{l}\text { Score } \\
\text { Gap \% }\end{array}$ & C.R. \\
\hline $\begin{array}{l}\text { Written } \\
\text { Materials }\end{array}$ & & & & & \\
\hline Folder & 1.7 & 43.33 & 1.25 & 58.33 & $2.32(*)$ \\
\hline Leaflet & 1.2 & 60 & 1.1 & 63.33 & $0.53(\mathrm{NS})$ \\
\hline Booklet & 1.5 & 50 & 1.2 & 60 & $1.55(\mathrm{NS})$ \\
\hline Farm journal & 1.3 & 56.66 & 1.2 & 60 & $0.529(\mathrm{NS})$ \\
\hline News letter & 1.3 & 56.66 & 1.1 & 63.33 & $1.05(\mathrm{NS})$ \\
\hline Bulletin & 1.4 & 53.33 & 1.1 & 63.33 & $1.57(\mathrm{NS})$ \\
\hline
\end{tabular}


Table.6 Degree of Contact of Farmers and Farmwomen with Extension Materials for learning and communications (Traditional/Folk Media)

\begin{tabular}{|l|l|l|l|l|l|}
\hline $\begin{array}{l}\text { Extension } \\
\text { Materials }\end{array}$ & $\begin{array}{l}\text { Mean Score } \\
\text { (Farmer) }\end{array}$ & $\begin{array}{l}\text { Score Gap } \\
\%\end{array}$ & $\begin{array}{l}\text { Mean Score (Farm } \\
\text { women) }\end{array}$ & $\begin{array}{l}\text { Score Gap } \\
\%\end{array}$ & C.R. \\
\hline $\begin{array}{l}\text { Traditional } \\
\text { Media/ Folk } \\
\text { media }\end{array}$ & & & & & \\
\hline Puppet Show & 2.75 & 8.33 & 2.6 & 13.33 & $1.24(\mathrm{NS})$ \\
\hline Folk Dance & 2.9 & 3.33 & 2.8 & 6.66 & $1.184(\mathrm{NS})$ \\
\hline Village Drama & 2.9 & 3.33 & 2.65 & 11.66 & $2.45(*)$ \\
\hline $\begin{array}{l}\text { Information } \\
\text { giving by using } \\
\text { drum by Dakua }\end{array}$ & 2.8 & 6.66 & 2.7 & 10 & $0.93(\mathrm{NS})$ \\
\hline Wall Paintings & 1.8 & & & & \\
\hline
\end{tabular}

Fig.1

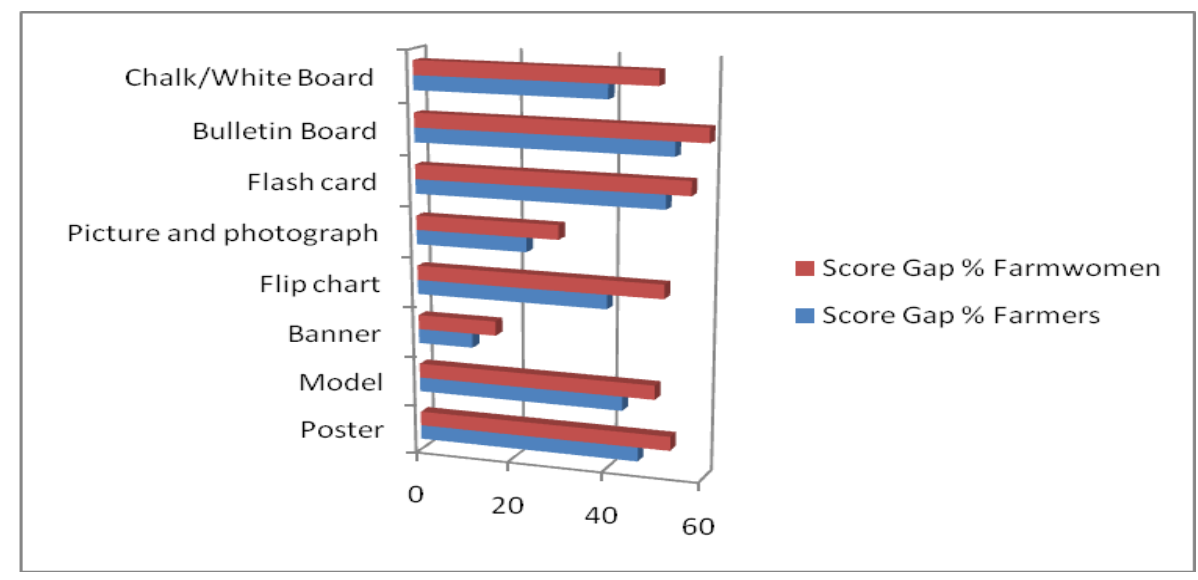

Fig.2

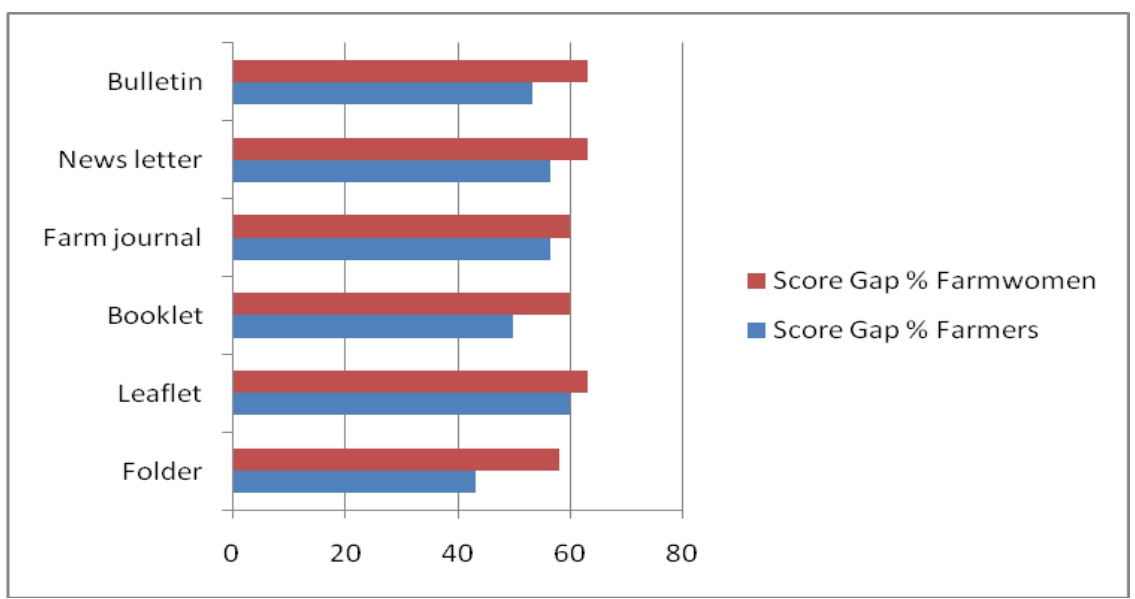


Fig.3

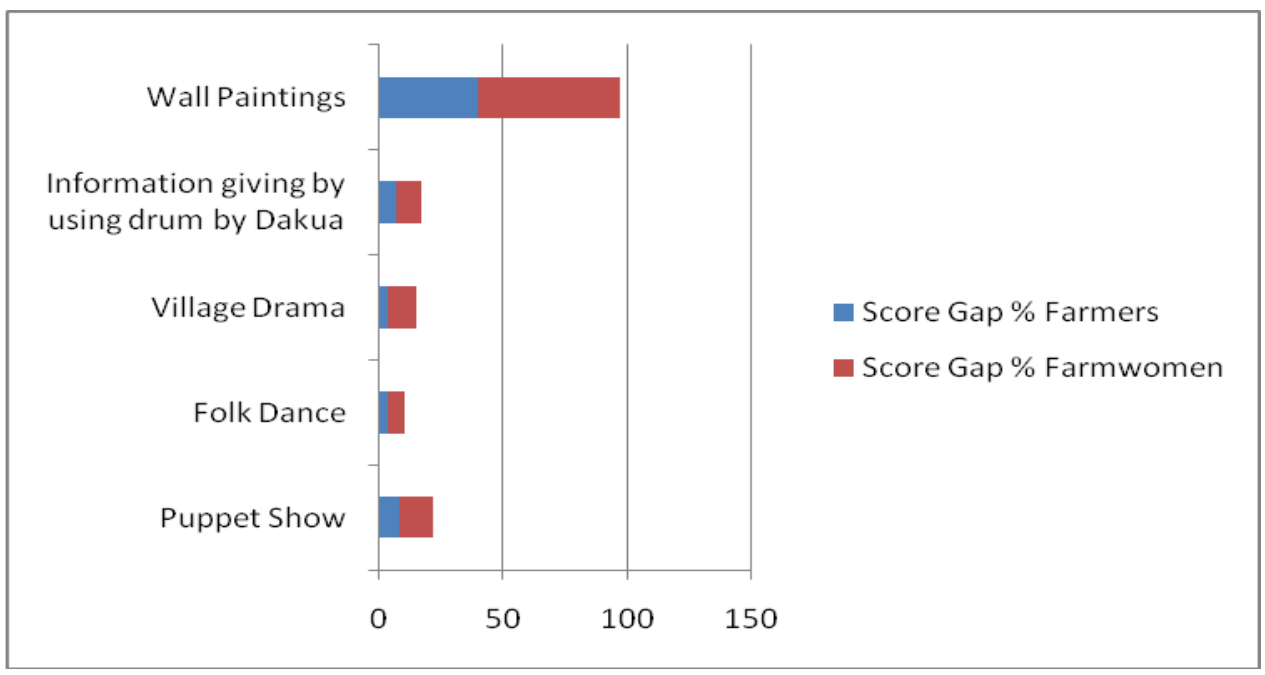

\section{Glimpses during data collection}
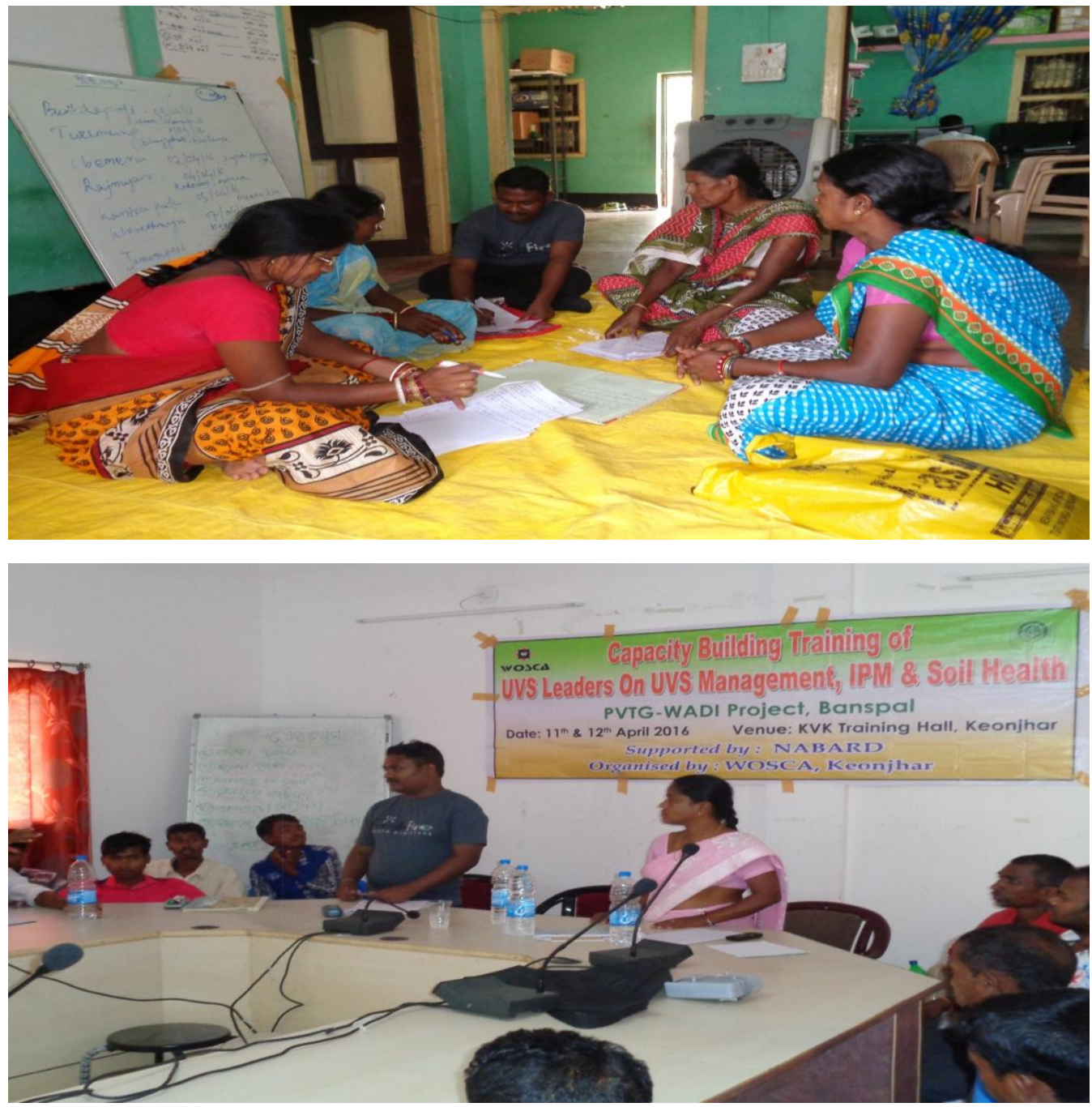
Summary and Conclusion are as follows:

Here the Researcher has the following findings as described as Summary and Conclusion

1. It was an encouraging trend that the respondents both farmer and farm women were in a good touch with exposure visit, group meeting and demonstration. However the significant C.R.Value with respect to result demonstration and exposure visit implied that the farm women were lagging behind the farmers in both these group communication methods. Therefore it was suggested that more number of farm women should be enrolled for result demonstration and exposure visits. This will make them more prone to adoption of technology and technical empowerment.

2. The result also depicted that high significant difference in contact with mass communication methods through gender line. The farmers and farm women significantly differ in contact with Radio and TV message, exhibition and campaign.

Therefore it was suggested to involve more no of farm women in campaign, exhibition, radio and TV message. As the score gap is very high with respect to farm publications the village youth club should play a vital role for dissemination of technology through farm publications.

3. The data concluded that farmers were getting information from various visual materials such as Banner, Picture and photograph, Flipchart and Chalk/WhiteBoard whereas farm women were getting information from Banner, Picture and photograph, Model and Chalk/WhiteBoard.

4. It also revealed that there was no significant difference of degree of contact among farmers and farm women with respect to visual materials.

However, the use of folder had a significant C.R.value which implied that the difference of use of folders by farmers and farm women was significant. That implied that farmers were using more folders than farm women for communication of information.

5. As the score gap is high with respect to exposure and contact with respondents with written communication materials due to illiteracy and ignorance, the social groups, youth clubs, community centers should be sensitized by the local extension agents for increasing the contact of respondents to written and printed materials.

6. The data concluded that farmers and farm women of the sample area were getting information from various traditional media such as folk dance, village drama, information giving by using drum by Dakua, and puppet show.

7. It also revealed that there was significant difference of degree of contact among farmers and farm women with respect to traditional media with wall paintings, and village drama.Therefore it may be concluded that the farmers were getting more information than farm women through village drama and wall paintings.

\section{Acknowledgement}

We are thankful to almighty for his Oceanic blessings and feel enthusiastic by contributing this article to the Society for Devt. of Farmers and Farm women in general and Research scientist in particular. For publication of this NAAS-5 rated journal, I am thankful to my guide and co-guides. For awarding of $\mathrm{PhD}$ Degree I am thankful to my Vice-chancellor, OUAT and for financial aid via OUAT-PhD Scholarship I am thankful to my University. For guidance and help to prepare this paper I am also thankful to World Journal and Team.

\section{References}

1. Agarwal, B (1981). Agricultural Modernization and Third World Women: Pointers from the Literature and an Empirical Analysis. Geneva: ILO. 
2. Gender Mainstreaming in Education: A Reference Manual for Governments and Other Stakeholders. London: Commonwealth Secretariat.

3. Food and Agriculture Organization (1999).

4. Hannan, Ferocious and AKM Abdul Hannan Buiyan (1994). Role of Women in Agriculture: Some Conceptual Issues.

5. Razavi, S and Miller, C (1997). Conceptual Framework for Gender Analysis within the Development Context. New York: UNDP Gender in Development Programme.

6. Beoku, Betts, J. (1990) Agriculture Development in Sierra Leone: Implications for Rural Woman in the
Aftermath of the Woman's decade, Africa today.

7. Brown, Lynn. R., and Haddad L. (March 1995) Time Allocation Patterns and time Burdens: A Gender Analysis of seven countries, The Gender CG Newsletter, International Food Policy Research Institute (IFPRI), Vol. 1, No 2.

8. Hulsebosch, Jositske, and Ombara, Doris, (1995). Towords Gender Balance in Irrigation Management: Experience in Kenya South West Karu Project Irrigation and Drainage System, Vol. 9: 1-14.

9. Khushk Ali M. and S. Hisbani (2004) Rural women at work.

10. censusindia.gov.in/Tables Published/S.

\section{How to cite this article:}

Bibhu Santosh Behera and Bibhuti Prasad Mohapatra. 2019. Comparative Analysis of Communication System of Farmers and Farm Women with the Extension Methods and Materials. Int.J.Curr.Microbiol.App.Sci. 8(12): 2590-2600. doi: https://doi.org/10.20546/ijcmas.2019.812.303 